\title{
NETHERLANDS YEARBOOK OF INTERNATIONAL LAW
}

2008 


\section{Netherlands Yearbook of International Law}




\title{
NETHERLANDS YEARBOOK OF INTERNATIONAL LAW
}

\author{
published jointly with the \\ Netherlands International Law Review \\ and under the auspices of the \\ Stichting T.M.C. Asser Instituut, \\ Institute for Private and Public \\ International Law, \\ International Commercial Arbitration \\ and European Law, \\ The Hague

\section{VOLUME XXXIX 2008}

$\mathrm{T} \cdot \mathrm{M} \cdot \mathrm{C} \cdot \mathrm{A}$ S S E R P R E S S 


\begin{abstract}
Aims and Scope
The Netherlands Yearbook of International Law was first published in 1970. It has two main aims. It offers a forum for the publication of scholarly articles of a more general nature in the area of public international law including the law of the European Union. In addition, it aims to respond to the demand for information on state practice in the field of international law. Each Yearbook therefore includes an overview of state practice of the Netherlands.
\end{abstract}

Under the combined subscription arrangements this volume of the Yearbook is linked to Volume 55 of the Netherlands International Law Review. Orders should be sent to: Cambridge University Press, Customer Service Department, The Edinburgh Building, Shaftesbury Road, Cambridge, CB2 2 RU, UK. From Volume 36 (2005) on, the Yearbook is also available online through the Cambridge Journals Online service, which can be found at $<$ http://journals.cambridge.org $>$. For further information you may visit $<$ www.asserpress.nl/cata/nyil/fra.htm $>$.

All correspondence with regard to the contents of the Yearbook should be addressed to the Managing Editor, T.M.C. Asser Instituut, P.O. Box 30461, 2500 GL The Hague, The Netherlands, e-mail: NYIL@asser.nl.

See page $\mathrm{X}$ for General information for authors.

\author{
Printed in the Netherlands \\ (C) Stichting T.M.C. Asser Instituut, The Hague, 2008 \\ Library of Congress Catalog Card Number 72-623109
}

ISBN 9789067043014
print: ISSN 0167-6768
online: ISSN 1574-0951

\title{
T.M.C. Asser Instituut - Institute for Private and Public International Law, International Commercial Arbitration and European Law
}

Institute Address: R.J. Schimmelpennincklaan 20-22, The Hague, The Netherlands; Mailing Address: P.O. Box 30461, 2500 GL The Hague, The Netherlands; Tel.: +3170 342 0300; Fax: +3170 3420 359; Internet: www.asser.nl.

Over forty years, the T.M.C. Asser Institute has developed into a leading scientific research institute in the field of international law. It covers private international law, public international law, including international humanitarian law, the law of the European Union, the law of international commercial arbitration and increasingly, also, international economic law, the law of international commerce and international sports law.

Conducting scientific research in the aforementioned domains is the main activity of the Institute. In addition, the Institute organizes congresses and postgraduate courses, undertakes contractresearch and operates its own publishing house.

Because of its inter-university background, the Institute often cooperates with Dutch law faculties as well as with various national and foreign institutions.

This publication is protected by international copyright law. All rights reserved. No part of this publication may be reproduced, stored in a retrieval system, or transmitted in any form or by any means, electronic, mechanical, photocopying, recording or otherwise without the prior written permission of the copyright owners. 


\section{BOARD OF EDITORS}

L.A.M.N. Barnhoorn

(Managing Editor)

T.M.C. Asser Instituut

M.K. Bulterman

Ministry of Foreign Affairs

I.F. Dekker

(General Editor)

Utrecht University

W.J.M.van Genugten

Tilburg University

Radboud University, Nijmegen

E. Hey

Erasmus University, Rotterdam

K. Peters

(Assistant Managing Editor)

T.M.C. Asser Instituut
P.A. Nollkaemper

(General Editor)

University of Amsterdam

F. Weiss

University of Vienna

W.G. Werner

VU University, Amsterdam

R.A. Wessel

University of Twente

\section{HONORARY EDITORS}

H. Meijers $\dagger$

University of Amsterdam
Ko Swan Sik

T.M.C. Asser Instituut

Erasmus University, Rotterdam 


\section{TABLE OF CONTENTS}

\section{Articles}

Fabian Amtenbrink, The multidimensional constitutional legal order of the European Union - a successful case of cosmopolitan constitution-building?

Ruth L. Okediji, WIPO-WTO relations and the future of global intellectual property norms

Jan Vanhamme, Formation and enforcement of customary international law: the European Union's contribution

Alexander Orakhelashvili, International law and geopolitics: one object, conflicting legitimacies?

\section{Documentation}

Classification Scheme

P.C. Tange, Netherlands state practice for the parliamentary year 2006-2007

M.A. van der Harst, Treaties and other international agreements to which the Kingdom of the Netherlands is a party - Conclusions and developments 2007

P.C. Tange, Netherlands municipal legislation involving questions of public international law, 2007

L.A.N.M. Barnhoorn, Netherlands judicial decisions involving questions of public international law, 2006-2007

S. Jansen en L. Wannet, Literature on Dutch state practice in the field of public international law, 2007

Table of cases

Index 


\section{ABBREVIATIONS}

AA Ars Aequi

Aanh. Hand. I/II Aanhangsel tot het Verslag der Mededelingen van de Eerste/Tweede

Kamer der Staten Generaal

AB Kort Administratiefrechtelijke Beslissingen Kort

$\mathrm{AB}$

Administratiefrechtelijke Beslissingen

AJIL

American Journal of International Law

ASIL Proc.

American Society of International Law Proceedings

BDIEL

Basic Documents of International Economic Law

Berkeley JIL

BGBl

BNB

Berkeley Journal of International Law

Bundes Gesetzblatt

Boston Univ. ILJ

Beslissingen in Belastingzaken Nederlandse Belastingrechtspraak

BVerfGE

Boston University International Law Journal

BYIL

Entscheidungen des Bundesverfassungsgericht

California LR

CMLRev.

British Yearbook of International Law

Columbia LR

California Law Review

Common Market Law Review

DD

Columbia Law Review

Duke JCIL

Delikt en Delinkwent

$\begin{array}{ll}\text { ECR } & \text { European Court Reports } \\ \text { EJIL } & \text { European Journal of International Law } \\ \text { ETS } & \text { European Treaty Series } \\ \text { European LJ } & \text { European Law Journal } \\ \text { European LR } & \text { European Law Review } \\ \text { Finnish YIL } & \text { Finnish Yearbook of International Law } \\ \text { GA Res. } & \text { UN General Assembly Resolutions } \\ \text { German LJ } & \text { German Law Journal } \\ \text { GYIL } & \text { German Yearbook of International Law } \\ \text { Hand. I/II } & \text { Verslag der Handelingen van de Eerste/Tweede Kamer der Staten Generaal } \\ \text { Harvard HRJ } & \text { Harvard Human Rights Journal } \\ \text { Harvard ILJ } & \text { Harvard International Law Journal } \\ & \\ \text { ICJ Rep. } & \text { International Court of Justice Reports } \\ \text { ICLQ } & \text { International and Comparative Law Quarterly } \\ \text { ILM } & \text { International Legal Materials } \\ \text { ILR } & \text { International Law Review } \\ \text { JB } & \text { Jurisprudentie Bestuursrecht } \\ \text { JCMS } & \text { Journal of Common Market Studies } \\ \text { JV } & \text { Jurisprudentie Vreemdelingenrecht }\end{array}$

Kamerstukken I/II Bijlagen bij het Verslag der Handelingen van de Eerste/Tweede Kamer der Staten Generaal 


\begin{tabular}{|c|c|}
\hline $\begin{array}{l}\text { Leiden JIL } \\
\text { LJN }\end{array}$ & $\begin{array}{l}\text { Leiden Journal of International Law } \\
\text { Landelijke Jurisprudentie Nummers website with full text Dutch case } \\
\text { law < www.rechtspraak.nl }>\end{array}$ \\
\hline $\begin{array}{l}\text { M en R } \\
\text { Melbourne Univ. LR } \\
\text { Michigan JIL } \\
\text { Minnesota LR } \\
\text { MRT }\end{array}$ & $\begin{array}{l}\text { Milieu en Recht } \\
\text { Melbourne University Law Review } \\
\text { Michigan Journal of International Law } \\
\text { Minnesota Law Review } \\
\text { Militair Rechtelijk Tijdschrift }\end{array}$ \\
\hline $\begin{array}{l}\text { NAV } \\
\text { NILR } \\
\text { NIPR } \\
\text { NJ } \\
\text { NJB } \\
\text { NJF } \\
\text { NY Univ. JIL \& Pol. } \\
\text { NY Univ. LR } \\
\text { NYIL } \\
\text { NZWehrr }\end{array}$ & $\begin{array}{l}\text { Nieuwsbrief Asiel- en Vluchtelingenrecht } \\
\text { Netherlands International Law Review } \\
\text { Nederlands International Privaatrecht } \\
\text { Nederlandse Jurisprudentie } \\
\text { Nederlands Juristenblad } \\
\text { Nederlandse Jurisprudentie Feitenrechtspraak } \\
\text { New York University Journal of International Law and Politics } \\
\text { New York University Law Review } \\
\text { Netherlands Yearbook of International Law } \\
\text { Neue Zeitschrift für Wehrrecht }\end{array}$ \\
\hline OJ & Official Journal of the European Communities \\
\hline $\begin{array}{l}\text { RdC } \\
\text { RGDIP } \\
\text { RIAA } \\
\text { RSV } \\
\text { RV } \\
\text { RvdW }\end{array}$ & $\begin{array}{l}\text { Recueil des cours } \\
\text { Revue Générale de Droit International Public } \\
\text { Reports of International Arbitral Awards } \\
\text { Rechtspraak Sociale Verzekeringen } \\
\text { Rechtspraak Vreemdelingenrecht } \\
\text { Rechtspraak van de Week }\end{array}$ \\
\hline SEW & $\begin{array}{l}\text { Sociaal-Economische Wetgeving - Tijdschrift voor Europees en } \\
\text { Economisch Recht }\end{array}$ \\
\hline $\begin{array}{l}\text { Stb. } \\
\text { Stc. }\end{array}$ & $\begin{array}{l}\text { Staatsblad van het Koninkrijk der Nederlanden } \\
\text { Nederlandse Staatscourant }\end{array}$ \\
\hline TIAS & Treaties and other International Acts Series \\
\hline $\begin{array}{l}\text { UBWV } \\
\text { Univ. PA LR } \\
\text { UNTS } \\
\text { USZ } \\
\text { Utah LR }\end{array}$ & $\begin{array}{l}\text { Unterrichtsblätter für die Bundeswehrverwaltung } \\
\text { University of Pennsylvania Law Review } \\
\text { United Nations Treaty Series } \\
\text { Uitspraken Sociale Zekerheid } \\
\text { Utah Law Review }\end{array}$ \\
\hline $\begin{array}{l}\text { Valparaiso Univ. LR } \\
\text { Virginia JIL }\end{array}$ & $\begin{array}{l}\text { Valparaiso University Law Review } \\
\text { Virginia Journal of International Law }\end{array}$ \\
\hline $\begin{array}{l}\text { Yale JIL } \\
\text { Yale L \& Pol. R } \\
\text { Yale LJ }\end{array}$ & $\begin{array}{l}\text { Yale Journal of International Law } \\
\text { Yale Law \& Policy Review } \\
\text { Yale Law Journal }\end{array}$ \\
\hline ZaöRV & eitsschrift für ausländisches öffentliches Recht und Völkerrecht \\
\hline
\end{tabular}




\section{GENERAL INFORMATION FOR AUTHORS}

\section{Embargo}

Articles submitted to NYIL should not be simultaneously under consideration elsewhere. Acceptance of the Editors offer to publish implies, that authors agree to an embargo on publication elsewhere, either in English or another language, for a period of two years following the year of publication of the Yearbook containing the article in question.

\section{Copyright}

Copyright is exclusively reserved to the author(s).

\section{Fees}

Authors will not receive a fee, but will be presented with a copy of the Yearbook containing their article, together with a total of 25 off-prints free of charge. Any additional copies of off-prints can be ordered prior to publication, and will be charged.

\section{Editorial policy}

All papers are refereed by the Board of Editors. The Board of Editors reserves the right to suggest modifications and/or additions to the paper submitted, and further reserves the right to reject, or to revoke acceptance or to withhold publication of any paper.

\section{Language}

Authors are requested to submit their paper in English. Papers accepted for publication may, at the discretion of the Editors, be linguistically revised.

\section{Proofs}

The author will receive proofs for correction. Corrections should be kept to a minimum. The only corrections which should normally be necessary are those relating to type-set errors or those which take account of important material or references not previously available, or subsequent developments of notes. Substantial modifications to the text or footnotes will not be permitted, except in consultation with and with the consent of the Editors.

\section{Submission of papers}

Contributions should be provided, on one side of A4 paper, paginated, double spaced together with an electronic copy on a clean new disk in Word or WordPerfect. However, the manuscript may also be submitted by e-mail attachment, together with the contributor's full mailing address. The maximum length of the article should be 450 words per page, 35 pages, including footnotes for a full article and 20 pages for a case-note.

An abstract of 150-250 words, and a list of no more than 10 keywords should be submitted. The text should be divided in sections and subsections.

Footnotes should be numbered consecutively throughout the text. The first footnote of each contribution marked with an asterisk should contain name, position and (institutional) affiliation for each author. Thereafter, footnotes should be numerical, starting with number 1 .

Authors should carefully check for errors before submitting. Authors are responsible for accuracy of quotations, for supplying complete and correct references, and for obtaining permission, where needed, to cite another author's material.

For house-style information please refer to the Managing Editor at $<$ nyil@asser.nl $>$, the rules of citation and points of style should be observed closely. 